Nigerian Journal of Physiological Sciences 22 (1-2): 59-63 @Physiological Society of Nigeria, 2007

Available online/abstracted at http://www.biolineinternational.org.br/njps; www.ajol.info/journals.njps; www.cas.org

\title{
CENTRAL NERVOUS SYSTEM DEPRESSANT ACTIVITY OF RUSSELIA EQUISETIFORMIS
}

\section{O. T. KOLAWOLE, J. M. MAKINDE ${ }^{1}$ and O.A OLAJIDE ${ }^{1}$}

\author{
Department of Pharmacology and Therapeutics, College of Health Sciences, Ladoke \\ Akintola University of Technology, Osogbo, Nigeria \\ ${ }^{1}$ Department of Pharmacology and Therapeutics, College of Medicine, University of Ibadan, Nigeria \\ E-mail: tymkol@yahoo.co.ukTel: +2348060470371
}

Summary: The central nervous system depressant activity of the crude methanol extract (REC) and fractions (RE1, RE2, and RE3) of Russelia equisetiformis were evaluated in mice using the following models: amphetamine - induced stereotypy, picrotoxin - induced convulsion and phenobarbitone sleeping time. At $200-400 \mathrm{mg} / \mathrm{kg}$, REC significantly increased phenobarbitone-sleeping time $(\mathrm{p}<0.05)$ in a dose- dependent manner and also reduced the sleep latency significantly $(\mathrm{p}<0.05)$. The fractions, at doses $1.5 \mathrm{mg} / \mathrm{kg}$ for RE1 and $20 \mathrm{mg} / \mathrm{kg}$ for RE2 and RE3 also significantly prolonged Phenobarbitone sleeping time and sleep latency $(\mathrm{p}<0.05)$. Picrotoxin - induced convulsion was not prevented by 100 $400 \mathrm{mg} / \mathrm{kg}$ of REC but this dose range significantly prolonged seizure latency. A significant reduction $(\mathrm{p}<0.05)$ in amphetamine - induced stereotype behavior was observed with $200 \mathrm{mg} / \mathrm{kg}$ REC, but there was no protection against amphetamine - induced mortality. The results of this study suggest that Russelia equisetiformis methanol extract possesses central nervous system depressant activities.

Key Words: Russelia equisetiformis, Phenobarbitone, stereotypy, anticonvulsant, Picrotoxin, amphetamine.

\section{Introduction}

Russelia equisetiformis is a plant that belongs to the family Scrophulariaceae (figwort family). Its common names are firecracker plant, coral plant, coral blow and fountain plant (Watkins and Sheehan, 1995). A few reference works available show that, on phytochemical screening, the plant has as part of its chemical constituents triterpenes and sterols, and that it lacks flavonoids and alkaloids (Abu-Mustafa $e t$ al, 1997; Burns et al, 2000).

There is growing interest in natural triterpenoids especially because of their wide spectrum of biological activities. They have been shown to be bactericidal, fungicidal, antiviral, cytotoxic, analgesic, sedative, spermicidal, anti-inflammatory, antiallergic and so on (Patocka, 2000). There are three main compounds of the triterpene group that have been extensively studied. These are lupeol, betulin and betulinic acid. Russelia equisetiformis which has been found to contain some of these compounds was investigated for central nervous system depressant activities.

\section{Materials And Methods \\ Plant Material}

The aerial part of $R$. equisetiformis was collected in March from New Bodija Extension,
Ibadan Southwest Nigeria. It was authenticated in the herbarium of Forestry and Research Institute of Nigeria (FRIN), Ibadan where voucher specimen was deposited (Voucher Sample Number: FHI 106504). The sample was air- dried at room temperature. It was then reduced to powdery form after drying, using electric blending machine.

Powdered sample of the plant was extracted in $100 \%$ methanol using a soxhlet extractor. The resulting crude methanol extract was then concentrated under reduced pressure at $40^{\circ} \mathrm{C}$ in a rotary evaporator to obtain a solid sample weighing $23.5 \mathrm{~g}$. Using column chromatography, different components of the methanol extract were eluted with chloroform/methanol solvent. They were pooled into a total of three fractions (RE1, RE2 and RE3) after TLC analysis. Animals

Male Swiss mice weighing 20-25g were housed in the pre-clinical animal house, College of Medicine, University of Ibadan, Nigeria. They were kept in standard cages, with a maximum of five animals in a cage. The animal house was properly ventilated. The animals were acclimatized in the laboratory area for two weeks before the commencement of the experiments. They were fed standard diet 
(Ladokun Feeds Ltd, Ibadan) and allowed free access to clean drinking water, delivered with special water dispensing bottles.

\section{Determination of Phenobarbitone Sleeping Time}

The method used by Bourin was adapted (Bourin et al, 1986). Briefly, the animals were divided into 14 groups of 5 mice each. Three doses of each of the extracts (REC, RE1, RE2 and RE3) were tested using a group of animals for each dose. The doses of the extracts were $100 \mathrm{mg} / \mathrm{kg}, 200 \mathrm{mg} / \mathrm{kg}$ and $400 \mathrm{mg} / \mathrm{kg}$ for REC; $0.5 \mathrm{mg} / \mathrm{kg}, 1.0 \mathrm{mg} / \mathrm{kg}$ and $1.5 \mathrm{mg} / \mathrm{kg}$ for $\mathrm{RE} 1$; $5 \mathrm{mg} / \mathrm{kg}, 10 \mathrm{mg} / \mathrm{kg}$ and $20 \mathrm{mg} / \mathrm{kg}$ for both RE2 and RE3. One group of animals each was pretreated with $2 \mathrm{ml}$ of normal saline and $2 \mathrm{mg} / \mathrm{kg}$ diazepam. All pretreatments were done intraperitoneally 30minutes before administration of sodium Phenobarbitone $(100 \mathrm{mg} / \mathrm{kg})$. Sleeping time was taken to be the time interval between loss and regain of righting reflex.

\section{Anticonvulsant Assay}

This assay was carried out according to the method described by Bourin et al, 1986. The animals were pretreated intraperitoneally with REC (100, 200 and $400 \mathrm{mg} / \mathrm{kg}$ ) and normal saline 30minutes before the administration of picrotoxin $(5 \mathrm{mg} / \mathrm{kg})$. The animals were observed for the onset of seizure for about 2 hours after intraperitonael injection of picrotoxin. The number of death and death latency (time between injection of picrotoxin and death) were recorded. Diazepam $(2 \mathrm{mg} / \mathrm{kg}$ ) was used as reference drug.

Table 1: Effect of REC on sleeping time

\begin{tabular}{llll}
\hline $\begin{array}{l}\text { Treatment } \\
\mathrm{n}=5\end{array}$ & $\begin{array}{l}\text { Dose } \\
(\mathrm{mg} / \mathrm{kg})\end{array}$ & $\begin{array}{l}\text { Sleep latency } \\
(\mathrm{min})\end{array}$ & $\begin{array}{l}\text { Sleeping time } \\
(\mathrm{min})\end{array}$ \\
\hline Saline & & $90.40 \pm 3.76$ & $108 \pm 8.83$ \\
Diazepam & 2 & $8.20 \pm 1.11^{\mathrm{c}}$ & $281.40 \pm 11.86^{\mathrm{c}}$ \\
REC & 100 & $86.20 \pm 6.10^{\mathrm{b}}$ & $127.80 \pm 11.43^{\mathrm{b}}$ \\
REC & 200 & $60.00 \pm 3.96^{\mathrm{b}}$ & $207.80 \pm 7.51^{\mathrm{c}}$ \\
REC & 400 & $54.40 \pm 2.69^{\mathrm{c}}$ & $226.80 \pm 13.55^{\mathrm{c}}$ \\
\hline
\end{tabular}

Each value represents the mean \pm SEM

$b=p<0.05 ; c=p<0.001$ compared with the control

Effects of Russelia equisetiformis Fractions on Phenobarbitone Sleeping Time

The results obtained from the study of the effect of fractions of effects of Russelia equisetiformis fractions on phenobarbitone sleeping time is presented in figures 1,2 and 3 . At $1.5 \mathrm{mg} / \mathrm{kg}, \quad \mathrm{RE} 1$ gave a significant
Protection Against Amphetamine - Induced Stereotypy

The method of Bourin (Bourin et al, 1986) was employed. Briefly, mice were divided into 5 groups of 5 animals each. Three groups were pretreated with REC (50, $100,200 \mathrm{mg} / \mathrm{kg}$ ) and one group each with Chlorpromazine $(2 \mathrm{mg} / \mathrm{kg})$ and normal saline. Amphetamine $(35 \mathrm{mg} / \mathrm{kg})$ was administered to animals in all the groups 30 minutes after the pretreatments. All administrations were done intraperitoneally. Each mouse was individually observed for 2 minutes at 10, 30, 60 and 90 minutes after amphetamine injection. Stereotype behavior was scored using the following scales: $1=$ Presence of stereotyped movement of the head and intermittent sniffing; 2 = Chewing, $3=$ Intense licking

\section{Statistical Analysis}

Differences between control and treatment groups were tested for statistical significance by Student's t- test. Differences were taken to be significant when $\mathrm{p}<0.05$.

\section{Results}

Effects of Russelia equisetiformis (REC) on Phenobarbitone Sleeping Time

The results obtained from the study of the effects of R.equisetiformis on phenobarbitone sleeping time are shown in Table 1. The extract gave a dose-dependent increase in the phenobarbitone sleeping time. The increase was significantly higher $(\mathrm{p}<0.05)$ at 200 and $400 \mathrm{mg} / \mathrm{kg}$ when compared with saline (control). There was also a significant $(p<0.05)$ reduction in the sleep latency at the same doses relative to control. 


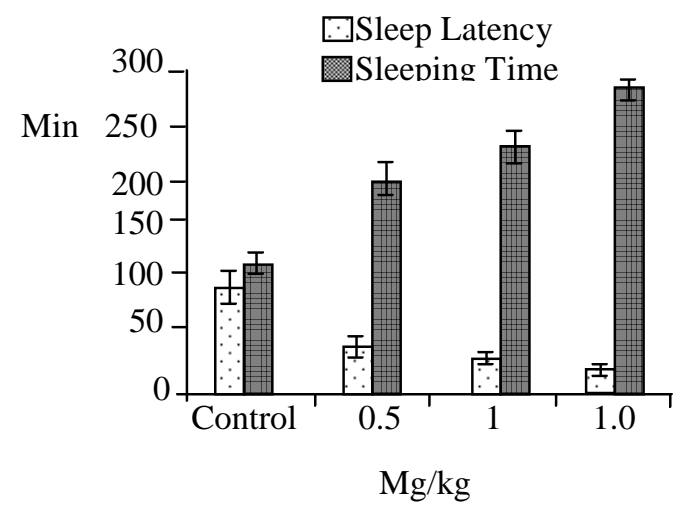

Fig. 1: Effect of RE1 on Sleep Latency and Sleeping Time $n=5$ : Each value represents the mean \pm SEM,.

$*=P<0.05$ compared with the control

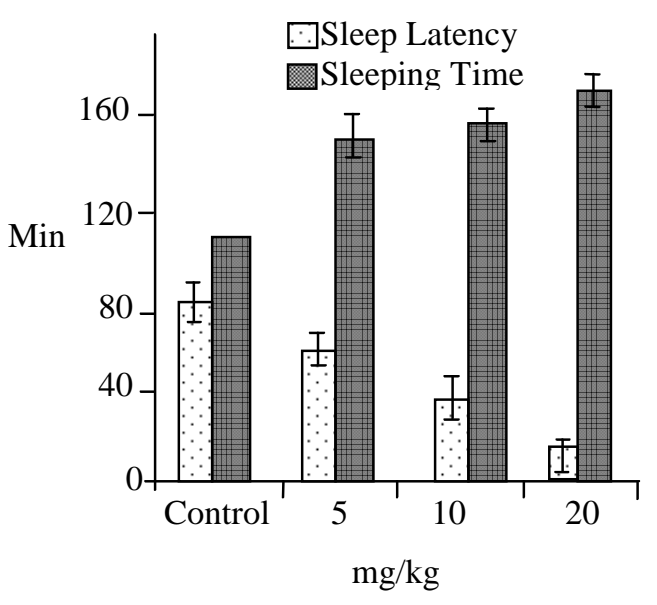

Fig. 3: Effect of RE3 on the Sleep Latency and Sleeping Time $n=5$ : Each value represents the mean \pm SEM,

$*=P<0.05$ compared with the control

Effects of Russelia equisetiformis (REC) on Picrotoxin - Induced Convulsion

The onset of seizure after picrotoxin injection was increased by REC at 100 and $200 \mathrm{mg} / \mathrm{kg}$, but was reduced with $400 \mathrm{mg} / \mathrm{kg}$ relative to control. Percentage death was similar among 100 and $200 \mathrm{mg} / \mathrm{kg}$ (40\%) while all the animals died in the group that received $400 \mathrm{mg} / \mathrm{kg}$. The results are presented in Table 2.

Effects of Russelia equisetiformis (REC) on Amphetamine - Induced Stereotypy

Figure 4 shows the results obtained from the effects of REC on amphetamine - induced stereotype behavior in mice. There was a significant reduction in stereotype behavior at $200 \mathrm{mg} / \mathrm{kg}$ of the extract. Within the first 10 minutes after the administration of $400 \mathrm{mg} / \mathrm{kg}$, all animals in this group died. So it was impossible to score animals in the group on stereotype behavior.

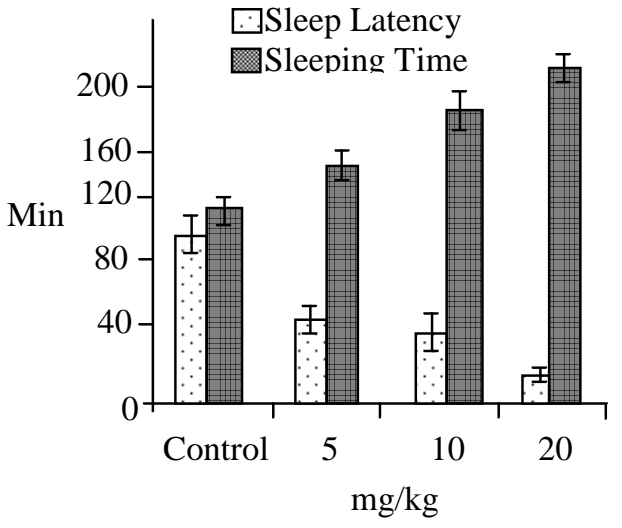

Fig. 2: Effect of RE2 on Sleep Latency and Sleeping Time. $n=5$ : Each value represents the mean $\pm S E M$,.

$*=P<0.05$ compared with the

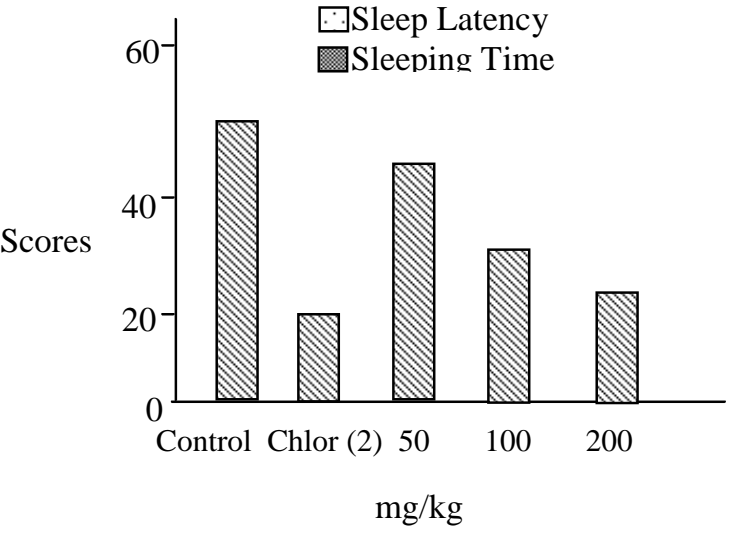

Chlor (2) $=2 \mathrm{mg} / \mathrm{kg}$ Chlorpromazine

Fig. 4: Effect of REC on Amphetamine - induced Stereotypy

Table 2: Effect of REC on picrotoxin - induced convulsion

\begin{tabular}{llll}
$\begin{array}{l}\text { Treatment } \\
\mathrm{n}=5\end{array}$ & $\begin{array}{l}\text { Dose } \\
(\mathrm{mg} / \mathrm{kg})\end{array}$ & $\begin{array}{l}\text { Onset of } \\
\text { seizure } \\
(\mathrm{min})\end{array}$ & $\begin{array}{l}\% \\
\text { Death }\end{array}$ \\
\hline Saline & & $\begin{array}{l}9.20 \pm \\
0.66\end{array}$ & 60 \\
& & $\begin{array}{l}0.66 \pm \\
14.40 \pm\end{array}$ \\
$\mathrm{REC}$ & 100 & $\begin{array}{l}0.92 \\
18.40 \pm\end{array}$ \\
& & 40 \\
$\mathrm{REC}$ & 200 & $\begin{array}{l}1.00 \\
6.00 \pm\end{array}$ & 100 \\
& & 0.40 & \\
REC & 400 & 23 & 20 \\
& &
\end{tabular}

Each value represents the mean \pm SEM. With diazepam, only one animal convulsed and died. 


\section{Discussion}

This study has established the central nervous system depressant properties of Russelia equisetiformis. The study demonstrated that $R$. equisetiformis caused an earlier onset of the effect of phenobarbitone (sleep latency) when compared with the control and it also increased the duration of action of phenobarbitone (sleeping time) significantly $(\mathrm{p}<0.05)$.

Since Gamma - aminobutyric acid (GABA) is the major inhibitory neurotransmitter in the central nervous system (Gingrich and Caron, 1993), it is possible that REC acts by potentiating GABAergic inhibition in the CNS via membrane hyperpolarization which leads to a reduction in the firing rate of critical neurons in the brain. This inhibition may be due to direct activation of GABA receptor by REC. It may also be due to enhanced affinity for GABA (Burh, 1997) or an increase in the duration of the GABA-gated channel opening (Stanley, 1995).

The CNS depressant activities of the extract was dose - dependent. However the fraction RE1 was relatively more toxic with as low as $10 \mathrm{mg} / \mathrm{kg}$ causing death within 5 minutes of administration. This necessitated the use of lower dose range for the evaluation of its effect on phenobarbitone sleeping time.

$R$ equisetiformis appears not to completely prevent picrotoxin-induced convulsion in mice at doses of up to $400 \mathrm{mg} / \mathrm{kg}$, but the seizure latency was significantly increased at $200 \mathrm{mg} / \mathrm{kg} \quad(\mathrm{p}<0.05)$. Since picrotoxin induces convulsion by blocking GABA-A receptors in the brain, leading to enhanced excitatory process which manifests as convulsion, the seeming inability of REC to prevent picrotoxin- induced convulsion suggests that the extract could not fully reverse the blockade of GABA-A receptor caused by picrotoxin (Seaman, 1987). However, the possibility of REC protecting mice against strychnine- induced convulsion cannot be ruled out, since strychnine acts via another channel, the glycine receptor (Porter, 1990).

Amphetamine - induced stereotype behavior was significantly reduced with $200 \mathrm{mg} / \mathrm{kg}$ of REC. This result suggests an interaction between the extract and catecholamines at functionally important central adrenergic or dopaminergic receptors. The stereotype behaviors induced by amphetamine results from excess catecholamine in the brain (Kent, 2001).

This marked increase in brain levels of catecholamines could have come about either by inhibition of catecholamine reuptake or by inhibition of monoamine oxidase. It could also have resulted from the release of dopamine from dopamine neurones leading to hyperdopaminergic activity (Ellenbroek, 1993). Any of these modes of action of amphetamine may be antagonized by REC to cause a fall in the brain level of catecholamine which manifests as reduced stereotype behavior. The observed protection against amphetamine induced stereotypy by REC was comparable to that offered by chlorpromazine, a dopamine receptor $\left(D_{2}\right)$ blocker. Hence, the probability of REC blocking dopamine receptor cannot be ruled out.

When $400 \mathrm{mg} / \mathrm{kg}$ of REC was coadministered with amphetamine, the animals convulsed to death within 5 minutes after administration. Since it is suspected that REC could be acting as a dopamine receptor blocker, the toxicity at this dose level may be seen as arising from extrapyramidal reactions typical of antipsychotic agents (Hevers and Luddens, 1998). Dopamine receptor blockade would lead to functional deficiency of dopamine in the nigra- striatum, a system that controls motor activity (Porter, 1990). So the absence of inhibitory dopaminergic system would give way to uncontrolled excitatory cholinergic mechanism that is responsible for the neuromuscular excitability which probably proceeded to convulsion (Foote and Morrison, 1987). This effect, combined with amphetamine toxicity such as hypertension, tachycardia, prolonged muscular hyperactivity, seizure and hyperthermia which can cause brain damage (Kane, 1999) probably led to the death of the animals. Thus, REC was unable to protect mice from amphetamine -induced mortality.

The overall results in this study indicate that $R$. equisetiformis has a depressant action on the central nervous system. Interactions with phenobarbitone, amphetamine and picrotoxin indicate a modulatory effect on brain functions that involves noradrenergic and dopaminergic transmission (Ellenbroek, 1993).

\section{References}

Abu-Mustafa, E. A., Bedour M. S., Boulos L, Elgamal, M. H. A., El- Mumajjed, D. T., Fayez, M. B. E., Girgis, A. N., Sallam, L. A. R. (1997). Constituents of local plants. XXIII.Tests of 350 accessions in a phytochemical screening program of Egyptains Plants. J.Ass. Adv Agr Sci Afri 4:61- 76

Bourin, M., Poisson, L., Larousse, C. (1986). Piracetam interaction with neuroleptics in psychopharmacological tests. Neuropsychobiology 19:93-96

Burh, A. (1997). Subtle changes in residue 77 of the gamma subunits of alpha $_{1}$ beta $_{2}$ 
gamma $_{2} \mathrm{GABA}_{\mathrm{A}}$ receptors drastically alter the affinity for ligands of the benzodiazepine binding site. J.Biol Chem 272:1179.

Burns, D., Reynolds, W. F. Buchanan, G., Reese, P. B., Enriquez, R. G. (2000). Assignment of $1 \mathrm{H}$ and $13 \mathrm{C}$ spectra and investigation of hindered side-chain rotation in lupeol derivatives. Magn Reson. Chem 387:488- 493.

Ellenbroek, B. A. (1993). Treatment of schizophrenia:a clinical and preclinical evaluation of neuroleptic drugs. Pharmacol \& Therapeut 57:1-78.

Foote, S. L., and Morrison, J. H. (1987). Extrathalamic modulation of cortical function. Ann. Rev.Neurosci. 10:6795.

Gingrich, J. A., and Caron, M. G. (1993). Recent advances in the molecular biology of dopamine receptors. Ann. Rev. Neurosci.16: 299

Hevers, W. and Luddens, H. (1998). The diversities of $\mathrm{GABA}_{\mathrm{A}}$ channel subtypes. Mol Neurobiol 18:35.

Kane, J. M. (1999). Pharmacologic treatment of schizophrenia. Biol Psychiatry 46:1396

Kent, R. O. (2001). Management of poisoned patients. In: Basic and Clinical Pharmacology, $8^{\text {th }}$ edition. Bertram G. Katzung (ed) McGraw- Hill New York. P.67.
Lindvall, O. and Bjorklund, A. (1983). Dopamine and norepinephrine-containing neuron system: their anatomy in the rat brain. In: chemical Neuroanatomy. (P.C. Emson, ed) Raven Press, New York p. 67.

Patocka, J. (2000). Biologically active pentacyclic triterpenes and their current medicine signification. J. Applied Biomedicine 1:7-12.

Porter, R. J. (1990). New antiepileptic agents: Strategies for drug development. Lancet 336: 423

Seaman, P. (1987). Dopamine receptors and the Dopamine hypothesis of schizophrenia. Synapse 1:133.

Stanley, K. J. (1995). Ionic mechanisms of neuronal excitation by inhibitory $\mathrm{GABA}_{\mathrm{A}}$ receptors. Science 269: 97.

Twyman, R. E. (1989). Differential regulation of $\mathrm{GABA}_{\mathrm{A}}$ receptor channels by diazepam and Phenobarbital. Ann Neurol 25: 213

Watkins, J. V. and Sheehan, T. J. (1975). Florida Landscape Plants. University press of Florida. P. 6-8.

Received: 25/9/2006

Accepted: $1 / 6 / 2007$ 